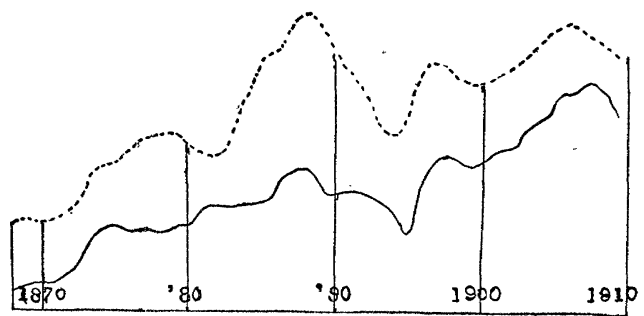

FIG. 15. Electricity and Magnetism; Dotted Line, Applied Mathematies ( $\frac{1}{4}$ scale).

fairly steadily toward that fraction. It has been mentioned already that 1873 was the year of publication of Maxwell's "Electricity and Magnetism," and of Thomson and Tait's "Natural Philosophy." Maxwell's book appears in German translation in 1883. About 1880 Hertz began his remarkable experimental work verifying the theories of Faraday and Maxwell, with effects certainly contributory to the swelling of this tide. An apparent ebb near 1894 is explained in part by the increasing preoccupation of the referee in that department. Immediately after that date the increase of matter is resumed, partly under the new stimulus of Röntgen rays (1897) and of the electron theory (about 1902). By comparison, this special impulse seems not to be shared by the other departments of applied mathematics.

A careful inspection of these graphs might lead some specialists to lament the constant shifting of the center of mathematical interest. To students, however, who are about embarking on the sea of research, it may yield such profitable hints as the mariner draws from a chart of prevailing winds and currents.

H. S. WHITE

VASSAR COLLEge

\section{NICHOLAI ALEXEYEVICH OUMOV}

The recent death of Professor Nicholai Alexeyevich Oumov deprived Russia and the world of one of those remarkable men, unfortunately rare in our age of sharply defined specialization, in whom the powers of analysis and synthesis were so well blended together, as to enable him to be more than simply a great physicist, or a great chemist, or a great cosmographer, but a great philosopher.

It seems that modesty is a usual attribute of greatness, and Oumov was a modest man, indeed. Perhaps this accounts for the fact that he is so very little known in this country and in England, although the continental Europe, especially Germany, knows him well and has a profound respect for his works. His biography, however, seems to be a matter of knowledge only within a small circle of his countrymen, and it seems desirable to supply this want.

Oumov was born in 1846. To his father, a physician by profession, he owes his profound and wide interest in physical science. At the age of twenty-three he was graduated by the faculty of physics and mathematics of the University of Moscow. After his graduation he entered the car-construction works of Williams and Buchteeff. Later on he registered at the St. Petersburg Technological Institute, but after two months' attendance, he received an offer to return to the University of Moscow and prepare for a professorship there.

In 1871, however, he received appointment as a privat-docent in physics at the University of Odessa, where, several years later, he was promoted to professorship. In 1893 he was transferred to the University of Moscow, where he lectured successively on general, mathematical and experimental physics.

In 1905 the Russian universities received a charter of autonomy, by which the administration of the institutions was left in the hands of the university council, while the student body received certain privileges of selfgovernment. However, towards the end of 1910, when the late Kasso became the Russian minister of education, attempts were made to deprive the universities of their autonomy. Early in 1911 a strike of the Moscow students, provoked by the agents of the police, as was later determined, gave the government the desired opportunity, and police control over the 
internal affairs of the Moscow University was established.

The rector of the university, Dr. Manouilov, went to St. Petersburg to protest against this, pointing out the fact that the administration of the university was able to take the proper measures, without police interference. He was informed by the minister that if the state of affairs, as it then existed, did not please him, he was at liberty to pursue any course he chose.

Immediately upon his return to Moscow, Dr. Manouilov resigned from his post at the university. Several other professors, led by Oumov, also tendered their resignations, as a protest against the action of the government.

At that time Oumov, as the professor of experimental physics, was in charge of the celebrated physical institute of the university. Several days after he tendered his resignation, he was ordered to leave the university $i m$ mediately. $\mathrm{He}$ was not even permitted to complete the experiments he had under way in his laboratories.

When this became known, a group of Moscow business men collected funds for the equipment of a new laboratory at the Free University of Sheniawsky, also at Moscow, and Oumov's work was transferred there. He remained at this university until his death.

This one fact is sufficient indication of the popularity which Oumov enjoyed in private life. He was beloved by his students, despite the fact that he was very exacting in his requirements. But it was well known that whenever the interests or the privileges of the student body were concerned. Oumov would always bring his powerful influence to bear upon his colleagues. Stern and dignifiedly scientific in the lecture hall and the laboratory, he was always kind, open-hearted and generous in private life. Student after student received financial assistance for the tuition from Oumov, but each one was made to promise never to mention this fact.

It is interesting that his favorite laboratory assistant, a man of scarcely any education, has recently been appointed to special instructorship at the university. His association with Oumov gave him a wonderful knowledge of physics. ${ }^{1}$

As far as Oumor's scientific work is concerned, it would be very difficult to give a full appreciation of it at the present time; like the majority of Russian professors he published comparatively little during his lifetime, and a considerable period will probably yet elapse before we have a complete study of his work.

There was, however, one characteristic feature of his scientific activity, of which we spoke at the very beginning. He was primarily a scientific philosopher, and it was this characteristic that made him different from other physicists. It was with a profoundly philosophical attitude that he regarded the different evolutionary phases of the human thought in the domain of physical phenomena. Professor Hrolson thus describes this characteristic side of Oumov's scientific make-up:

$\mathrm{He}$ possessed a remarkable talent that enabled him to grasp quickly the essence of the views and the interpretations of the world, prevalent at the given moment, analyze the causes, often remote and deep-seated, that led to the rise of new hy. potheses and theories, and then, by means of a clever synthesis, represent the results of the new evolutions of science. 2

He was a splendid lecturer and he was often invited to speak at scientific congresses. In his speeches

clear popular presentation of the results of new scientific works was blended with a philosophical interpretation of them, which often made them assume entirely new aspects.

The esteem in which Oumov was held by his fellow scientists in Russia may be seen from the fact that on the "First Russian Congress of Teachers of Physics, Chemistry and Cosmography," held in December, 1913, Oumor was elected president, as the "oldest Russian professor of physics, a profound thinker and a remarkable scientist." At this congress he delivered a famous speech on the "Evolution

1 I owe these facts concerning Oumov's private life to my friend, Mr. E. Dourmashkin, of $\mathrm{New}$ York City, who had studied under Oumor at the University of Moseow.

2 Professor O. Hvolson, "Retch," Petrograd, January 19, 1915. 
of the Physical Sciences and Its Idealistic Significance."

His scientific activity was profound and many-sided. His splendid knowledge of physics, in the progress of which he was interested all his life, and his tremendous general erudition, enabled him to work in many departments of physical science. The names of some of his works are very suggestive of this manifoldness of interest: "A Theory of Action at a Distance and Its Application to the Laws of Electrostatics and Electrodynamics," "The Laws of the Solution of Certain Salts," "The Geometrical Significance of Frenkel's Integrals," "An Attempt of Discovering the Laws of Heat Energy in Chemical Reactions," "Uber eine Methode objektiver Darstellung der Eigenschaften des polarisierten Lichtes," "The Formation of Drops in a Magnetic and an Electric Field."

In physics he was equally at home in experimental methods and in the mathematical analysis. After leaving the University of Moscow, however, he gave himself up almost exclusively to theoretical work, especially in the domain of the principle of relativity. Some of his results in this direction were described in a speech on "The Characteristic Features and Problems of the Modern Scientific Thought," delivered before the general meeting of the second Mendelejer Congress. ${ }^{3}$

Oumov was the president of several scientific societies in which he was invariably the guiding spirit. For a short time he edited a splendid scientific magazine, The Word of Science, which, however, did not exist long.

\section{Leo Pasvolsky}

\section{NeW YORK CITY}

\section{CLASSIFICATION OF TECHNICAL LITERATURE}

Delegates from about twenty national technical and scientific societies met in the United Engineering Society Building, 29 West 39th street, New York City, on May 21, 1915, to perfect a permanent organization, the purpose being to prepare a classification of the litera-

3 Unfortunately the speech is not available in this country. ture of applied science which might be generally accepted and adopted by these and other organizations.

There was a generally expressed opinion that such a classification, if properly prepared, might well serve as a basis for the filing of clippings, for cards in a card index, and for printed indexes; and that the publishers of technical periodicals might be induced to print against each important article the symbol of the appropriate class in this system, so that by clipping these articles a file might be easily made which would combine in one system these clippings, together with trade catalogues, maps, drawings, blue prints, photographs, pamphlets and letters classified by the same system.

By request, Mr. W. P. Cutter, the librarian of the Engineering Societies' Library, and a delegate from the American Institute of Mining Engineers, read a paper on "The Classification of Applied Science" in which, after describing the existing classifications, of on $\theta$ of which he is the author, he stated that, in his opinion, no one of these, although having excellent features, was complete and satisfactory enough to be worthy of general adoption. $\mathrm{He}$ outlined a plan whereby a central office could collate all the existing classifications, and, with the help of specialists in the various national societies interested, might compile a general system, which, although perhaps not absolutely perfect, might meet with general acceptance and adoption.

Permanent organization was effected by the election of the following officers: Chairman, Fred R. Low; secretary, W. P. Cutter; executive committee; the above, with Edgar Marburg, H. W. Peck, Samuel Sheldon.

It was agreed that a special invitation to participate by the appointment of a delegate be sent to other national societies which might be interested in the general plan.

The following societies were represented by delegates: Samuel Sheldon, library board, United Engineering Society; Richard Moldenke, American Foundrymen's Association; C. Clifford Kuh, Society for Electrical Development; Cullen W. Parmelee, American 